\title{
ПИТАННЯ МЕТОДОЯОГІї
}

\author{
Олександр Киричок
}

\section{ЧИ МОЖЕ КИЕВОРУСЬКА ПОЛІТИЧНА ПИСЕМНІСТЬ БУТИ ОБ'ЄКТОМ ДОСЛІДЖЕННЯ 3 ІСТОРІЇ ФІЛОСОФІЇ УКРАЇНИ?}

Історико-філософські дослідження києворуської писемності, які розпочалися ще в середині XIX ст., до сьогодні змушені в гострих дискусіях відвойовувати свою наукову легітимність. Показово, що замітку під назвою «Чи була в Давній Русі філософія?» авторитетний фахівець у цій галузі В. В. Мильков вважав за потрібне опублікувати порівняно нещодавно - у 2012 році [Мильков, 2012]. Хоча автор категорично наполягає на тому, що «зусиллями кількох поколінь дослідників філософська складова давньоруської спадщини утверджена в її правах» [там само], насправді, києворуська писемність як об’єкт дослідження з історії філософії України постійно ставиться під сумнів через методологічні упередження, ближчі або віддаленіші від науковості. М.В.Симчич у одній із свої статей загострює проблему ідентифікації української філософії як чітко окресленого об'єкту історикофілософського дослідження й обстоює тезу, що історію філософії України «...слід сприймати як дослідницький проект - проект роботи 3 джерелами» [Симчич, 2012: c. 90]. 3 цим, в цілому, можна погодитися, однак стосовно києворуських джерел, як специфічного об'єкту історико-філософських студій, хотілося би зробити декілька зауважень.

Насамперед, в дослідженні києворуських писемних пам'яток, з одного боку, ми маємо справу з відображеною в них синкретичною культурою, де погляди на світ, людину чи на їх пізнання поставали єдиним цілим, невіддільними одні від одних, а 3 іншого, ми повинні штучно накладати на цю культуру методологічну схему, що передбачає диференціацію онтологічних, антропологічних, етичних та інших проблем, виходячи 3 певних сучасних уявлень про дані аспекти філософського знання. Однією з найменш вивчених сторін культури Київської Русі є відображені в писемних пам'ятках засади політичної філософії та ідейне тло, що їх оточувало. Саме вони й стануть предметом нашого дослідження, в якому ми спробуємо показати наукову легітимність подібних студій.

Найчастіше вивчення писемних пам'яток Київської Русі зводиться до виокремлення певних політично-філософських ідей у їхньому змісті, проте, ми вважаємо, що для повноцінного, всебічного й комплексного історико-філософського дослідження цього недостатньо. Останнє має містити: 1) окреслення кола києворуських писемних

(C) О. Киричок, 2014 
джерел, 3 яких ми можемо вилучити певний політично-філософський зміст або отримати свідчення про розвиток філософської культури; 2) віднайдення античних, західноєвропейських, візантійських, давньоболгарських чи інших витоків даних джерел та розкриття специфіки впливу політичного середовища на зміст писемної спадщини Київської Русі; 3) дослідження особливих атрибутів києворуської писемності, котрі перетворювали його на самостійну й дієву політичну реальність; 4) аналіз певних форм організації писемного тексту, що відігравали в києворуські часи роль засобів політичної маніпуляції; 5) дослідження впливу писемної спадщини Київської Русі на політику наступних століть та іï функціонування в сучасних політичних практиках.

Розглянемо послідовно кожен з цих п'яти аспектів.

1. Історико-філософське дослідження має починатися з відбору писемних джерел, необхідних для його реалізації. У їхній множині умовно можна виділити дві складові - джерела «універсальні» (що містили набір ідей, тією чи іншою мірою притаманних усій політичній філософії Середньовіччя) та «партикулярні» (що відображали локальні політичні проблеми та були приналежними, насамперед, до спадщини Київської $\mathrm{Pyci}^{1}$ ). «У великому їх масиві, - пише М. М. Громов, - можна умовно виділити три групи джерел за ступенем їхньої насиченості філософським змістом» [Громов, Козлов, 1990: с. 15]. Такими групами дослідник вважає: 1) тексти 3 «виразно вираженою філософською проблематикою»; 2) «морально-напутньою спрямованістю» й ін., що «безпосередньо прилягають до філософської літератури й містять серйозні роздуми про світ і людину» [Громов, Козлов, 1990: с. 15-16]; 3) «3 явно нефілософським змістом», однак такі, що можуть містити опосередковані свідчення про давньоруську свідомість [там само]. Водночас тут постає питання - чи дійсно в писемності Київської Русі існували джерела першої групи, тобто тексти, які можливо було б кваліфікувати як «політично-філософські» ${ }^{2}$ ? Виявляється такі тексти були - це «Послання про піст» митрополита Никифора, де середньовічний автор, на основі модифікованої та інкорпорованої в києворуський грунт політичної філософії Платона, окреслив цілком завершену систему філософських поглядів на природу влади, держави, ідеального правителя тощо [див.: Киричок, 2007; 2008]. Окрім цього києворуська писемність мала достатню кількість текстів другої групи, які однозначно не можна кваліфікувати як «політичнофілософські», але варто вважати такими, що прилягали до них і містили універсальний фонд політичних ідей Середньовіччя, а саме теократичну концепцію та теорію «священної держави», питання взаємодії світської та церковної влад, образ ідеального правителя та його чеснот, уявлення про внутрішньополітичні й зовнішньополітичні відносини, проблему політичного та юридичного статусу вільної й невільної людини, поняття «своя-чужа» земля тощо. Можна досить чітко виокремити також коло писемних пам'яток, де вони були представлені, а саме комплекс текстів світського та канонічного права, переклади грецьких «Номоканонів», новел Юстиніана, «Еклоги», «Хроніки» Георгія Амартола, корпус літописної літератури, «Ізборніки» 1073 та

${ }^{1}$ Ці терміни використовує І. Я. Лисий [Лисий, 2012].

2 Звісно ж, якщо спиратися не на модель інституалізованої політичної філософії, сформовану тільки в XX ст., а розуміти цю філософію ширше, включаючи домодерну «класичну політичну філософію», представлену мислителями Античності та Середньовіччя, як церобили, наприклад, автори проекту «History of political philosophy» під керівництвом Л. Штрауса й Д. Кропci [History of political philosophy, 1987]. 
1076 pp., афористична збірка «Бджола», «Слово про Закон і Благодать» Іларіона, твори Луки Жидяти, Кирила Туровського та Володимира Мономаха [див.: Dvornik, 1956]. Всі інші джерела можуть використовуватися залежно від того, чи містять вони «опосередковані вказівки» на політичну або філософську освіченість Київської Русі, й чи можуть «показати існування в ній певної філософської культури» [Чижевський, 1930] $]^{3}$.

3. Наступним кроком має стати віднайдення античних, західноєвропейських, візантійських, давньоболгарських чи інших витоків вищезгаданих ідей, з'ясування відповідних текстуальних паралелей, ідентифікація головних філософських персоналій, шкіл чи систем, у яких вони могли бути запозичені. Проте все це - лише проміжна ланка на шляху до аналізу впливу політичного середовища на зміст писемності, адже використання даних ідей залежало не лише від їхнього візантійського чи західноєвропейського походження, але й від особливостей політичних практик, в межах яких вони виникали та функціонували. Політичне середовище, з одного боку, було джерелом адаптації «універсальних» політичних ідей, з іншого ж - народжувало «партикулярні» проблеми, серед яких, звісна річ, виділялися теза про велич Руської землі, грунтована на своєрідних рефлексіях про геополітичне становище Русі, а також ідея єдності Київської Русі на основі подолання князівських міжусобиць та впровадження в політичну практику різних моделей «права вотчини», родинного права («листвиці»), «договірного права» тощо. Партикулярні ідеї випливали з києворуських політичних реалій і були представлені в «Слові о полку Ігоревім», «Слові про князів», «Слові про загибель Руської Землі», літописній спадщині тощо.

3. Поряд зі з'ясуванням ідейного змісту писемних джерел та його витоків, історико-філософське дослідження передбачає вивчення особливих політичних атрибутів києворуського письма, котрі перетворювали його на окрему, досить дієву політичну реальність. Слід враховувати той факт, що письмо за часів Київській Русі осмислювалось як певна сакральна практика, подібна до створення Святого Письма, й це, безумовно, відігравало вирішальну роль в ідеологічному утвердженні та сакралізації інститутів князівської влади та києворуської держави ${ }^{4}$. Написаний текст, на відміну від усного, апріорі мав претензію на політичну істинність. Використання політичними практиками цих та інших атрибутів письма, наприклад, відпочатково закладеної в нього «влади всезагальності» [Пролеєв, 2005: с. 86], претензії на обраність та високий політичний ранг писців, втаємниченість писемного ремесла, низка символічних властивостей, що асоціювалися з ознаками політичної влади (непорушність інвектив, претензія на вічність тощо), особливий статус шрифту й матеріалу, на якому відтворювалося політичне письмо, - все це робило його важливим магічним та владним ресурсом, дія якого не обмежувалася києворуським періодом. Цей аспект києворуського письма майже не розглядався в сучасній історико-

${ }^{3}$ Судячи 3 усього, поняття «філософська культура» в Дмитра Чижевського й Вілена Горського трактується подібно [див.: Горський, 1980; Горський, 1981: с. 80-81.; Горский, 1984]. Щоправда, Чижевський більше акцентував увагу на відшуканні опосередкованих «слідів філософії» в писемних джерелах. На практиці відділити пласт політично-філософських ідей від ідей політичних фактично неможливо й тому таке розділення досить умовне, хоча багато хто $з$ дослідників приймає його як робочий момент дослідження.

${ }^{4}$ «Яке ж джерело ідеологічних чар письма? - запитує Р. Р. Вахітов - ...архетипним прообразом письма, так би мовити, протописьмом, є не що інше як Абсолютна Книга, Одкровення Боже...» [Вахітов] 
філософській науці. Проте, низка методологічних знахідок у працях Мішеля Фуко, Жана Бодріяра, Жака Дериди, Ролана Барта, Жан-Франсуа Ліотара, Ернесто Лакло, Шанталь Муф, Славоя Жижека, Джона Грея й інших авторів [див.: Русакова, 2009: c. 225-226], котрі зверталися до політичних атрибутів письма в межах критики лібералізму, може бути перенесена й на дослідження несучасних і неліберальних суспільств та продуктивно використана при розгляді феномену києвруського письма.

3. Поряд із дослідженням загальних політичних атрибутів письма, необхідним $є$ визначення та аналіз певних форм організації тексту, що відігравали в києвроуські часи роль прийомів політичного впливу. Серед них пріоритетними були політичні лексеми, метафори, топіки та наративи. Кожна з цих одиниць активно ангажувалася політикою, виконуючи цілу низку завдань. Залучення до історико-філософського дослідження методів дескриптивної та історичної лексикології показує, наприклад, що базові політичні лексеми Київської Русі («держава», «влада», «мир», «війна») мали не тільки когнітивне навантаження, але й використовувались як інструменти політичного примусу, вживалися не стільки у вигляді «понять», здатних охопити сенс політичних інститутів та процесів, скільки у вигляді «слів», що накидали певні політичні ідеї, спонукали до політичних дій, розмічали простір для подальшої їх інтерпретації ${ }^{5}$. Базові антропоморфні метафори писемної спадщини Київської Русі, що можуть бути успішно вивчені за допомогою інкорпорованих в історикофілософське дослідження методів політичної метафорології ${ }^{6}$, поставали не просто як риторичні фігури, а мали яскраво виражені політичні функції, відіграючи роль засобу утвердження, легітимації та сакралізації інститутів влади та держави, а також використовувалася києворуською політикою для утвердження думки про природність і «органічність» існування влади чи держави як «єдиного тіла». Політичні наративи в Лаврентіївському, Іпатіївському та Новгородському літописах, «КиєвоПечерському патерику», творах Борисо-Глібського циклу, що можуть бути віднайдені й досліджені за допомогою методів політичної наратології [Олещук, 2010], використовувалися в Київській Русі для утвердження ідеї родинного старійшинства та встановлення політичної ієрархії. Великий когнітивний і водночас політичний вплив мали також топіки чеснот ідеального правителя - достатньо поширені текстуальні шаблонові конструкції писемної спадщини Київської Русі.

5. Зрештою, останнім з аспектів має стати дослідження впливу києворуської писемної спадщини на політичне життя наступних століть та особливості ії функціонування в сучасній політичній практиці. Відзначимо, що здатність писемності мати політичний вплив була осмислена й навіть певною мірою легітимізована в часи Київської Русі. Церква, головний генератор писемних текстів, наголошувала на своєму праві впливати на політичну дійсність, адресуючи власні (насамперед епістолярні) твори представникам києворуської влади, чим, до речі, продовжувала

${ }^{5}$ Відмінність між «поняттями» і «словами» принципова для Квентіна Скіннера. Критикуючи підхід Раймонда Вільямса, викладений у його знаменитій книзі «Ключові слова» [Williams, 1985], К. Скінер писав, що нам необхідно бути обережнішими при встановленні взаємозв'язку між вживанням слів і розумінням понять; слова й поняття - не одне й те ж, між ними існують систематичні відношення, які потребують вивчення [див., наприклад, Скиннер, 2005: с. 144-145].

6 Політична метафорологія в наш час набуває рис нового напряму, зокрема у лінгвістиці. Загальний огляд зарубіжної літератури з цього питання [див. Будаев, Чудинов, 2008]. На наш погляд, iї надбання можуть бути успішно використані в історико-філософських дослідженнях. Про методологічні основи зарубіжної політичної метафорології [див.: Чудинов, 2011]. 
давню візантійську традицію. Серед києворуських джерел саме в межах цієї традиції слід розглядати текст «Повчальних глав диякона Агапіта імператору Юстиніану», цей своєрідний компендіум ідей ранньопатристичної політичної філософії, що, на думку В. Е. Вальденберга, «для руської політичної думки... був посередником у передачі ідей античної філософії» [Вальденберг, 1926: с. 34], а також два листи києворуського митрополита Никифора: невідомому князю («На латину») та Володимиру Мономаху («Про піст»). Особливо цікавою $є$ остання праця, щодо якої досить часто повторюється думка про іiі нібито сумнівну приналежність до києворуської культури, адже їі написав грекою митрополит-грек, що, найімовірніше, навіть не спромігся оволодіти до пуття слов'янською мовою. Однак звернення до «зовнішніх» ознак аж ніяк не применшує значення цього твору для політичної дійсності Київської Русі, оскільки саме в царині політичної філософії Никифор демонструє найоригінальнішу позицію, відходячи від простого переповідання християнізованих платонівських тез і репрезентуючи великою мірою незалежні погляди й аналогії, закорінені в києворуський грунт. Окрім того, у творах Никифора ми можемо віднайти не тільки «критичний», але й «конструктивний» аспект, за якими інколи розрізняють «філософію політики» й «політичну філософію» ${ }^{7}$. Погляди Никифора - це саме «політична філософія», певна програма дій, модель політичної поведінки, яку він намагався накинути Мономахові. Аналогічні моделі ми можемо знайти й у інших писемних пам'ятках Київської Русі, наприклад, літописних зображеннях ідеального князя, «Слові про Закон і Благодать» Іларіона та ін. Зрештою, у києвроуських текстах можна зустріти й прямі політичні інвективи, що закликають князів до тих чи інших політичних дій. Наприклад, у «Слові о полку Ігоревім» автор пропонує давньоруським князям об'єднатися та єдиним фронтом захищати цілісність і єдність Руської землі. Окрім того, недостатньо розробленою донині залишається тема впливів писемності Київської Русі на політику наступних століть та їі відображення в сучасній політичній практиці [див.: Ричка, 2012]. Факти, що засвідчують використання києворуської писемності політикою пізніших часів, є безсумнівними. Без них не обійшлося у виробленні ідеології «третього Риму», сакралізації держави й створенні концепту «Святої Русі», формуванні образу «колиски трьох братніх народів» чи культивуванні патріотичного пафосу на прикладі «Слова о полку Ігоревім» в радянські часи [див.: Вдовина, 2013: с. 49-50], зрештою, використовується вона й сучасними ідеологами «Руського міру» та їхніми опонентами.

Отже, на основі вивчення політичного змісту києворуської писемності, його ідейних та соціальних витоків, атрибутивних і формальних властивостей письма та впливу останнього на політичне середовище, ми можемо отримати цілісний комплексний аналіз києвруських писемних джерел як політичного явища, що, як випливає 3 вищесказаного, може стати достатньо чітко окресленим предметним полем дослідження з історії філософії України.

${ }^{7}$ Слід зазначити, що далеко не всі дослідники проводять демаркаційну лінію між цими двома поняттями. Дослідженню відмінностей між термінами «філософія політки» та «політична філософія» в російському науковому та філософському дискурсі присвятила статтю I. В. Мельникова [див.: Мельникова, 2010]. На думку автора, в Росії чітко розрізняють ці поняття тільки Б. Г. Капустін і Т. О. Алєксєєва, інші дослідники довільно використовують дані терміни. 


\section{СПИСОК ЛІТЕРАТУРИ}

Будаев Э. В., Чудинов А. П. Зарубежная политическая метафорология. - Екатеринбург: Уральский гос. пед. университет, 2008. - 248 с.

Вальденберг B. E. Наставление писателя VI в. Агапита в русской письменности // Византийский временник. - Л. - 1926. - Т. XXIV. - С. 27-34.

Вахитов Р. Идеологические чары письма // Електронний ресурс. Режим доступу: http://nevmenandr. net/vaxitov/scripta. php

Вдовина О. Я. Філософська думка Київської Русі очима українських радянських дослідників // Філософська думка. - 2013. - № 1. - С. 48-56.

Горский В. С. Понятие «философская культура» в истории философской и общественной мысли народов СССР // Диалектика интернационального и национального в развитии общественной мысли. - Кишинев: Иштица, 1984. - С. 116-124.

Горський В. С. Историко-философское истолкование текста. - К.: Наукова думка, 1981. $205 \mathrm{c}$.

Горський В. С. Поняття «філософська культура» в історико-філософській науці // Філософська думка. -1980 . - № 4. - С. 60-71.

Громов М. Н., Козлов Н. С. Русская философская мысль X-XVII веков: Учебное пособие. - М.: Изд-во МГУ, 1990. - 288 с.

Киричок О. Б. «Політична філософія» давньоруського митрополита Никифора // Філософські ідеї в культурі Київської Русі. - Полтава, 2008.- С. 75-90.

Киричок О. Б. Спроба синтезу релігійних, філософських та політичних ідей у «Посланні про піст» митрополита Никифора // Колізії синтезу філософії і релігії в історії вітчизняної філософії (до 180-річчя Памфіла Юркевича та 130-річчя Семена Франка): Український часопис російської філософії. Вісник Товариства російської філософії при Українському філософському фонді. - Вип. 7.- Полтава: АСМI, 2007. - С. 474-479.

Лисий I. Я. Ще раз про національну ідентичність філософії // Філософські ідеї в культурі Київської Русі. - 2012. - Вип. 5. - С. 189-208.

Мельникова И. В. Философия политики и политическая философия в современном российском научном дискурсе // Електронний ресурс. Режим доступу: http://www. polygnozis. $\mathrm{ru} /$ default. asp? num $=6 \&$ num $2=500$

Мильков В. В. Была ли философия в Древней Руси? // Електронний ресурс. Режим доступу: http://iph. ras. ru/uplfile/rusph/biblio/milkov/ran_02_11_2012.pdf

Олешук П. Теоретичні засади аналізу політичних наративів як засобу дослідження політичного дискурсу // Електронний ресурс. Режим доступу: http://www. viche. info/journal/2014/

Пролеєв С. В. Метафізика влади. - К.: Наукова думка, 2005. - 374 с.

Ричка В.М. Пригадування Русі (осмислення спадщини св. Володимира в українській суспільно-політичній думці XVII ст.) // Український історичний журнал. - 2012. № 1. - C. 29-45.

Русакова О.Ф. Современные трактовки предметной области политической философии: методологический анализ // Научный ежегодник Института философии и права Уральского отделения Российской академии наук. - 2009. - Вып. 9. - С. 225-226.

Симчич М. В. «Українська філософія»: історико-філософський канон чи дослідницький проект? // Гуманітарні студії. - 2012. - Вип. 12. - С. 90.

Скиннер К. Язык и политические изменения // Логос. - 2005. - № 3(48). - С. 143-152.

Чижевский Д. И. Платон в Древней Руси // Записки Русского Исторического общества в Праге. - 1930. - № 2. - С. 71-82.

Чудинов А. П. Методология зарубежной политической метафорологии // Современная политическая лингвистика: тезисы Международной научной конференции. - Екатеринбург: Изд-во УрГПУ, 2011. - С. 286-289.

Dvornik F. Byzantine political Ideas in Kievan Russia // Dumbarton Oaks Papers. - 1956. - Vol. 9/10. - P. 75-121. 
Чи може києворуська політична писемність бути об'єктом дослідження...

History of political philosophy / Edited by Leo Strauss and Joseph Cropsey. Third edition. - Chicago:

University of Chicago Press, 1987. - $980 \mathrm{p}$.

Williams R. Keywords: A Vocabulary of Culture And Society. - Oxford: Oxford UP, 1985 - 352 p.

Стаття отримана редакцією 03.02.2014

\section{Oleksandr Kyrychok}

\section{IS IT POSSIBLE THAT KYIV RUS' POLITICAL WRITINGS WILL BECOME A RESEARCH OBJECT OF THE HISTORY OF UKRAINIAN PHILOSOPHY?}

This article is devoted to political philosophy in the texts of Kyiv Rus. The author decides that the program of such research should include: delineation of Kyiv Rus range of written sources where we can find certain political and philosophical content; research of attributes Kyiv Rus' writing, which turned it into an independent political reality; analysis of certain forms of written text, which were being used as a tool political manipulation; study of influence of the written heritage of Kyiv Rus on the policy of following centuries and policy today.

Oleksandr Kyrychok, candidate of sciences in philosophy, doctoral candidate at Hr. Skovoroda Institute of Philosophy of the NA S of Ukraine.

Олександр Киричок, кандидат філософських наук, докторант Інституту філософії імені Г. С. Сковороди НАН України.

Александр Киричок, кандидат философских наук, докторант института философии имени Г. С. Сковороды НАН Украины. 